\title{
МИКРОБИОТА КИШЕЧНИКА ЗДОРОВЫХ НОВОРОЖДЕННЫХ ДЕТЕЙ: НОВЫЕ ТЕХНОЛОГИИ ДИАГНОСТИКИ - НОВЫЙ ВЗГЛЯД НА ПРОЦЕСС СТАНОВЛЕНИЯ
}

Т. В. Припутневич ${ }^{1}$, Е. Л. Исаева В. В. Макаров², С. М. Юдин²

'Национальный медицинский исследовательский центр акушерства, гинекологии и перинатологии имени академика В. И. Кулакова, Москва, Россия

2 Центр стратегического планирования и управления медико-биологическими рисками здоровью, Москва, Россия

\begin{abstract}
В настоящее время не существует критериев адекватной оценки качественного и количественного состава микробиоты кишечника новорожденных детей, что не дает возможности выявить на ранних сроках патологический процесс и скорректировать его. Целью исследования было изучить становление микробиоты кишечника у здоровых новорожденных в городе Москве, рожденных самопроизвольно и путем операции кесарева сечения, с помощью методов культуромики, протеомики и молекулярно-генетических технологий. Обследовано 66 детей: 33 ребенка, рожденных самопроизвольно, и 33 - путем операции кесарева сечения. Образцы просветной микрофлоры собирали на первые, седьмые и 30-е сутки жизни. Выделено 136 видов микроорганизмов, относящихся к 40 родам. Показано, что кесарево сечение тормозит процесс нормального становления микрофлоры кишечника, и в течение изучаемого периода (первого месяца жизни) микробиоценоз кишечника у таких детей не достигает показателей у детей, рожденных самопроизвольно. Статистически достоверно в группе самопроизвольных родов преобладали бифидобактерии (частота их встречаемости в титре $10^{9}-10^{12} \mathrm{KOE} /\ulcorner$ составила 84\% против 33\% при титре $10^{5}-10^{12} \mathrm{KOE} /\ulcorner$ в группе кесарева сечения). В то же время у детей, рожденных самопроизвольно, по сравнению с детьми, рожденными путем кесарева сечения, отмечена статистически достоверно более низкая частота обнаружения клостридий (33,3 и 65,4\% соответственно) и лактозоотрицательных штаммов Escherichia coli (2,4 и 19,4\% соответственно)
\end{abstract}

Ключевые слова: микробиота, новорожденные, микробиота кишечника

Информация о вкладе авторов: Т. В. Припутневич - планирование исследования, организация микробиологических исследований, интерпретация данных; Е. Л. Исаева и В. В. Муравьева — проведение микробиологических исследований, подготовка черновика рукописи; А. Б. Гордеев - анализ и интерпретация данных; В. В. Зубков — планирование исследования, организация сбора проб фекалий; Л. А. Тимосеева и М. К. Месян - сбор проб фекалий; Е. Шубина — проведение секвенирования; В. В. Макаров и С. М. Юдин — планирование исследования.

Соблюдение этических стандартов: исследование одобрено этическим комитетом НМИЦ АГП им. В. И. Кулакова (протокол заседания № 4 от 12 апреля 2018 г.). Родители всех детей, включенных в исследование, подписали добровольное информированное согласие на участие в исследовании.

$\triangle$ Для корреспонденции: Алексей Борисович Гордеев ул. Академика Опарина, д. 4, г. Москва, 117997; gordeew@vega.protres.ru

Статья получена: 28.08.2019 Статья принята к печати: 11.09.2019 Опубликована онлайн: 28.09.2019 DOI: $10.24075 /$ vrgmu.2019.063

\section{GUT MICROBIOTA OF HEALTHY NEWBORNS: NEW DIAGNOSTIC TECHNOLOGIES — NEW OUTLOOK ON THE DEVELOPMENT PROCESS}

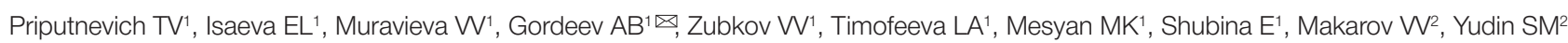

${ }^{1}$ National Medical Research Center for Obstetrics, Gynecology and Perinatology named after Academician V. I. Kulakov, Moscow, Russia

${ }^{2}$ Center for Strategic Planning and Management of Medical and Biological Health Risks, Moscow, Russia

Currently, there are no criteria allowing to adequately assess composition and volume of the newborns' gut microbiota, which prevents early detection of the pathological processes and appropriate intervention. This study aimed to apply the methods of culturomics, proteomics and molecular genetic technologies to investigate the development of gut microbiota in healthy newborns delivered in the city of Moscow both vaginally and through a cesarean section. We examined 66 children, 33 of them delivered vaginally and 33 by cesarean section. The luminal bacterial flora samples were collected on the 1 st, 7 th and 30 th days of life. There were 136 species of microorganisms belonging to 40 genera identified. We established that cesarean section slows down normal development of the gut microflora: through the follow-up period (1 month of life), gut microbiocenosis in such children did not yield the results on par with those registered in children born vaginally. Bifidobacteria were significantly more common in the vaginal delivery group: $84 \%$ of $10^{9}-10^{12} \mathrm{CFU} / \mathrm{g}$ versus $33 \%$ of $10^{5}-10^{12} \mathrm{CFU} / \mathrm{g}$ in the cesarean section group. At the same time, the former group had significantly less clostridia (33.3\% and 65.4\%, respectively) and lactose-negative Escherichia coli strains (2.4 and $19.4 \%$, respectively) than the latter group.

Keywords: microbiota, newborns, gut microbiota

Author contribution: Priputnevich TV — study planning, organization of microbiological tests, data interpretation; Isaeva EL and Muravieva WV — conducting microbiological tests, draft authoring; Gordeev AB - data analysis and interpretation; Zubkov W - study planning, feces samples collection organization; Timofeeva LA and Mesyan MK — feces collection; Shubina E — sequencing; Makarov W and Yudin SM — study planning.

Compliance with ethical standards: the study was approved by the Ethics Committee of National Medical Research Center for Obstetrics, Gynecology and Perinatology named after Academician V. I. Kulakov (meeting minutes № 4 of April 12, 2018). Parents of all children included in the study signed the voluntary informed consent to participate in the study.

$\triangle$ Correspondence should be addressed: Alexey B. Gordeev

Akademika Oparina, 4, Moscow, 117997; gordeew@vega.protres.ru

Received: 28.08.2019 Accepted: 11.09.2019 Published online: 28.09.2019

DOI: 10.24075/brsmu.2019.063

В современных условиях характер микробной колонизации кишечника, в том числе у новорожденных детей, претерпел существенные изменения в связи с увеличением контингента женщин с осложненным течением беременности, возрастанием стрессовых воздействий, экологическим неблагополучием и бесконтрольным применением антибиотиков.

Углубленное изучение кишечной микробиоты с использованием возможностей культуромики, высокотехнологичных методов идентификации выделенных 
микроорганизмов (MALDI-TOF MS, секвенирования последовательностей гена 16S pPHK), а также современных технологий метагеномного анализа позволяет значительно расширить представление о ее видовом многообразии.

Принятые в настоящее время нормативы по качественному и количественному составу микробиоть кишечника [1-3] на этом фоне требуют корректировки. На сегодняшний день отсутствуют четко разработанные критерии оценки состояния микробиоты кишечника новорожденных, которые позволили бы своевременно корректировать выявленные нарушения и на ранних этапах влиять на патологический процесс, например развитие некротизирующего энтероколита у недоношенных детей. Существует крайне мало работ, в которых представлены статистически обработанные данные по качественному и количественному составам микробиоты кишечника новорожденных детей $[4,5]$.

Целью исследования было с помощью методов культуромики, протеомики и молекулярно-генетических технологий оценить становление микробиоты кишечника у здоровых новорожденных в городе Москве, рожденных самопроизвольно и путем операции кесарева сечения.

\section{ПАЦИЕНТЫ И МЕТОДЫ}

Проспективное исследование выполняли на когорте здоровых доношенных новорожденных. Рандомизацию проводили блочным методом, в результате которого были сформированы две группы детей:

1) группа I - 33 ребенка, родившихся самопроизвольно;

2) группа II - 33 ребенка, родившихся путем операции кесарева сечения.

Детей отбирали согласно следующим критериям включения в исследование: гестационный возраст 38-40 недель; оценка по шкале Апгар на первой и пятой минутах жизни - 8-9 баллов; масса тела - более 2800 г. Всем новорожденным выполняли клинические анализы крови и мочи для исключения инфекционной патологии или других фракторов, способных повлиять на формирование микробиоты кишечника. Все дети находились на грудном вскармливании, и в единичных случаях детей докармливали искусственными смесями. У всех матерей не было отмечено длительного безводного промежутка; антибиотики во время беременности принимали три женщины; истмико-цервикальная недостаточность имела место у четырех женщин (6\%). В случае оперативного родоразрешения женщины получали амоксиклав в качестве антибиотикопрофилактики до и во время операции.

У новорожденных проводили трехкратный отбор проб фекалий: в первые сутки, конце первой недели и конце первого месяца жизни. Образцы мекония, полученного во время первой дефекации, или кала, собранные со стерильной пеленки в стерильный пластиковый контейнер, в течение 2 ч доставляли в лабораторию и незамедлительно приступали к посеву.

Изучение состава микробиоты кишечника новорожденных проводили с использованием расширенного спектра селективных и неселективных питательных сред и инкубированием в аэробных, микроаэрофильных и анаэробных условиях.

Посев мекония и кала проводили согласно принятым методикам [3, 6] на следующие питательные среды. Для выделения факультативно-анаэробных и аэробных микроорганизмов использовали колумбийский кровяной агар, хромогенную среду Brilliance, сальмонелла-шигелла- агар, декстрозный агар Сабуро (Oxoid; Великобритания), маннит-солевой агар (Himedia; Индия), среду для выявления и дифференциации Streptococcus agalactiae (CHROMagar; Франция), энтерококковый агар, агар Эндо (ФГУН «ГИЦПМ и Б»; Россия). Лактобациллы культивировали на среде лактобакагар (ФГУН «ГИЦПМ и Б»; Россия). Строгие анаэробы выделяли на агаре для бифидобактерий (Himedia; Индия), прередуцированном агаре Шедлера с необходимыми добавками, основном агаре для анаэробов, перфрингенс агаре, железосульфитном агаре, селективном агаре для Clostridium difficile (Oxoid; Великобритания). Для культивирования микроаэрофилов использовали $\mathrm{CO}_{2}$ инкубатор (Jouan; Франция) с концентрацией $\mathrm{CO}_{2}$ 5\%. Строгие анаэробы культивировали в анаэробном боксе (Jouan; Франция) в атмосфере трехкомпонентной газовой смеси ( $\mathrm{N}_{2}-80 \%$; $\left.\mathrm{CO}_{2}-10 \% ; \mathrm{H}_{2}-10 \%\right)$. Для контроля стерильности использовали тиогликолевый бульон (Oxoid; Великобритания).

Идентификацию микроорганизмов осуществляли с помощью времяпролетного MALDI-TOF мaсcспектрометра AutoFlex III c программным обеспечением Maldi BioTyper (Bruker Daltoniks; Германия) версии 3.0. При получении значений SCORE > 2,0 культуру считали с высокой вероятностью идентифицированной до вида. При значениях SCORE в диапазоне 1,7-2,0 культуру считали идентифицированной до рода.

Для всех трудноидентисицируемых штаммов (при значении SCORE < 2,0) проводили секвенирование последовательностей гена $16 \mathrm{~S}$ рPНК. ДНК культур выделяли с использованием набора реагентов для выделения ДНК «Проба-ЦиТо» («ДНК-технология»; Россия). Для секвенирования использовали два фрагмента ДНК: ампликон длиной 440 п. Н., соответствующий позициям 339-785 гена $16 \mathrm{~S}$ рPHК, и ампликон длиной 1340 п. Н., соответствующий позициям 42-1380 гена $16 \mathrm{~S}$ рРНК. Амплификацию проводили с использованием детектирующего амплификатора ДТпрайм («ДНКтехнология»; Россия). Секвенирование осуществляли на приборе 3130 Genetic Analyzer (Applied Biosystems; США) с использованием набора BigDye ${ }^{\mathrm{TM}}$ Terminator v3.1 Cycle Sequencing Kit (Applied Biosystems; США) согласно протоколу производителя. Для видовой идентификации использовали свободно доступный в Интернете программный пакет BLAST (National Center for Biotechnology Information; США).

При статистической обработке данных для определения различий в частоте встречаемости микроорганизмов в зависимости от способа родоразрешения использовали точный тест Фишера. В качестве описательной статистики для характеристики степени микробной обсемененности использовали медиану и интерквартильное расстояние (ИКР).

\section{РЕЗУЛЬТАТЫ ИССЛЕДОВАНИЯ}

В первой временной точке обследовано 66 детей, по 33 ребенка из каждой группы. У каждого пятого ребенка меконий оказался стерильным, причем у детей II группы в 2 раза чаще по сравнению с I группой (9 и 4 соответственно; $p>0,05)$. У детей с положительными результатами посевов мекония выделена разнообразная микрофлора (63 вида, средний показатель видового разнообразия составил 3,8 вида на одного ребенка). Наиболее часто (в 60\% случаев в титре $10^{2}-10^{3} \mathrm{KOE} /\ulcorner$ после самопроизвольных родов и в 70\% случаев в титре 102-104 KOE/г - после операции) выделяли грамположительные факультативно- 
анаэробные микроорганизмы, представленные 10 родами: Staphylococcus, Streptococcus, Enterococcus, Micrococcus, Gemella, Globicatella, Granulicatella, Rothia; Corynebacterium, Bacillus. Обращает на себя внимание, что у 12,2\% детей ॥ группы и у 6,1\% детей I группы обнаружен Staphylococcus aureus (S. aureus). Escherichia coli, в норме составляющая значительную часть нормофлоры кишечника, при самопроизвольных родах выделена почти в 3 раза чаще (24,2 и 9,1\%; p > 0,05). Прочие энтеробактерии также чаще выделяли у детей I группы (27 и 15\% соответственно; p > 0,05). Pseudomonas aeruginosa обнаружена только у одного ребенка II группы.

Наиболее важную роль в становлении микробиоты кишечника новорожденного играют лактобациллы и бифидобактерии. Эти микроорганизмы обнаружены уже в первые сутки жизни. В группе I колонизация кишечника лактобациллами оказалась значительно выше (18 и 3\% соответственно; $p>0,05)$, и это были Lactobacillus crispatus и Lactobacillus jensenii, относящиеся к числу доминирующих видов в вагинальной микробиоте здоровых женщин. Бифидобактерии также чаще выделяли у детей группы (9 и 3\% соответственно; $p>0,05$ ). Ими оказались Bifidobacterium bifidum, B. longum, B. adolescentis. Бактероиды в первые сутки жизни обнаружили лишь у одного ребенка I группы. Прочие анаэробы (вейлонеллы, превотеллы и кампилобактеры) выделяли практически только во II группе.

Ввиду отказа некоторых родителей от участия в исследовании или возникновения инфекционного заболевания часть детей выбыла из исследования в течение первой недели жизни, и во второй точке было обследовано 52 ребенка: 25 детей из І группы и 27 детей из ІІ группы.

Средний показатель видового разнообразия возрос по сравнению с первой точкой почти в 3 раза и составил 9,4 вида на одного ребенка. Как и в первые сутки жизни, в обеих группах наиболее часто встречались грамположительные факультативно-анаэробные микроорганизмы (9 родов). Их титр заметно вырос: после естественных родов - до $10^{7}-10^{11}$, после кесарева сечения - до $10^{7}-10^{12} \mathrm{KOE} /$, а частота встречаемости составила 100\% в обеих группах. Увеличилась частота выделения S. aureus: у 44\% детей | группы и у 55,6\% детей || группы. Расширилась представленность энтерококков с двух до шести видов: Enterococcus faecalis, E. durans, E. faecium, E. gilvus, E. avium, E. gallinarum. Доминирующую позицию, как и в первые сутки жизни, занимал E. faecalis, колонизировавший кишечник большей части новорожденных в обеих группах (80\% - в I группе и 88,9\% - во II группе).

Видовой спектр грамотрицательной фракультативноанаэробной микрофлоры расширился с 6 до 15 видов, относящихся к семейству Enterobacteriaceae. E. coli при самопроизвольных родах по-прежнему выделяли чаще (64\% - в I группе и 44,4\% - во II; $p$ > 0,05). Прочие энтеробактерии высевали примерно с одинаковой частотой в обеих группах.

Видовой состав лактобацилл обогатился новыми видами: L. paracasei, L. curvatus, L. gasseri, L. fermentum, L. rhamnosus. Необходимо отметить, что виды лактобацилл, доминирующие в вагинальной микробиоте здоровых женщин (L. crispatus, L. jensenii и L. gasseri), обнаружены только в I группе.

Статистически достоверные различия наблюдали в представленности бифидобактерий. Если в группе I частота их встречаемости составила 84\%, а титр находился в диапазоне $10^{9}-10^{12} \mathrm{KOE} /$, то во ॥ группе бифидобактерии выделены только у 33\% в титрах $10^{5}-10^{12} \mathrm{KOE} / г(p<0,05)$. Видовой спектр бифидобактерий расширился с 3 до 7 видов: B. adolescentis, B. breve, $B$. dentium, B. catenulatum, B. bifidum, B. longum, $B$. animalis. Некоторые виды обнаружены только в одной из групп: B. adolescentis и B. catenulatum (только в I группе) и B. dentium и $B$. animalis (только во II группе).

К седьмым суткам жизни микробиота в значительной степени обогатилась за счет прочих облигатных анаэробов (11 родов): Bacteroides, Parabacteroides, Veillonella, Clostridium, Fusobacterium, Ruminococcus, Eubacterium, Eggerthella, Actinomyces, Collinsella, Propionibacterium. При этом бактероиды, представленные Bacteroides fragilis, B. ovatus, B. vulgatus, B. uniformis, Parabacteroides distasonis, выделены только у детей, рожденных самопроизвольно. Существенной разницы в частоте обнаружения клостридий (Clostridium perfringens, C. butyricum, C. innocuum, C. tertium) не выявлено. У одного ребенка II группы выделен штамм c. difficile. В обеих группах возросла колонизация кишечника вейлонелами.

Таким образом, к седьмым суткам жизни существенно увеличилось видовое разнообразие, касающееся различных групп микроорганизмов, как факультативно-анаэробного, так и облигатно-анаэробного происхождения. Бисидобактерии, лактобациллы и бактероиды преобладали в группе I.

В третьей точке обследовано 50 детей: 24 ребенка из группы I и 26 детей из группы II. Средний показатель видового разнообразия составил 10,1 вида на одного ребенка. Как и в более ранние периоды, наиболее представленной была группа грамположительных факультативно-анаэробных микроорганизмов (7 родов). Частота выделения S. aureus мало изменилась в сравнении с седьмыми сутками в | группе (58,3\%) и значительно выросла во || группе (76,9\%). Видовой состав энтерококков пополнился еще двумя видами: E. casseliflavus и E. raffinosus.

В составе грамотрицательной факультативно-анаэробной микрофллоры выявлено 11 видов из семейства Enterobacteriaceae и один вид неферментирующих бактерий - Stenotrophomonas maltophilia. E. coli при самопроизвольных родах по-прежнему выделялась чаще (75\% в І группе и 61,5\% - во II; $p$ > 0,05). Прочие энтеробактерии несколько чаще высевали у детей II группы (66,7 и 73\% соответственно; $p>0,05)$.

Видовой состав лактобацилл расширился до 15 видов за счет L. reuteri, L. casei, L. vaginalis, L. brevis, L. helveticus, L. acidophilus, причем в I группе выделяли почти вдвое большее количество видов. Видовой спектр бифидобактерий увеличился на один вид B. ruminantium. Наиболее часто выделяли B. longum (58,3\% в I группе и 26,9\% - во II) и B. bifidum (33,3 и 34,6\% соответственно).

Облигатные анаэробы пополнились родами Sutterella и Peptoniphilus. Бактероиды (6 видов), представленные B. fragilis, B. thetaiotaomicron, B. vulgatus, B. uniformis, B. cellulosilyticus, Parabacteroides distasonis, за исключением одного случая после кесарева сечения, выделены только у детей, рожденных путем самопроизвольных родов.

Наметилась статистически достоверная разница в частоте обнаружения клостридий (C. perfringens, C. butyricum, C. tertium, C. ramosum, C. paraputrificum, C. difficile): у 33,3\% детей в I группе и 65,4\% - во II ( $p<0,05)$. Во II группе выделено в 2 раза больше видов клостридий. У одного ребенка II группы выделен C. difficile.

Дрожжевые грибы рода Candida обнаружены в обеих группах только на 30 -е сутки жизни менее чем у 10\% детей. 
Таким образом, на 30-е сутки жизни микробиота кишечника вне зависимости от способа родоразрешения представлена поликомпонентными ассоциациями микроорганизмов, относящихся к факультативным и облигатным анаэробам. В то же время наметились определенные различия, касающиеся облигатной и транзиторной составляющей микробиоты. Так, при самопроизвольном родоразрешении видовой состав лактобацилл был более разнообразным (почти вдвое большее количество видов), чаще выявляли виды, колонизирующие влагалище здоровых женщин. Бактероиды были преимущественно выделены у детей, рожденных самопроизвольно, а клостридии при большем видовом разнообразии, напротив, у детей, рожденных путем операции кесарева сечения. Условно-патогенные факультативные анаэробы (S. aureus и энтеробактерии, за исключением E. coli) чаще колонизировали детей, рожденных оперативным путем.

Гемолитические штаммы Enterococcus sp. и E. coli в обеих группах детей встречались с одинаковой частотой: Enterococcus sp. соответственно по 8,3\% в каждой группе и E. coli - 9,5 и 9,7\% соответственно. Лактозоотрицательные штаммы E. coli статистически достоверно чаще (в 8 раз) выделяли у детей II группы (19,4 и 2,4\% соответственно; $p<0,05)$.

Суммарно в процессе исследования было выделено и идентифицировано 136 видов микроорганизмов, относящихся к 40 родам: Staphylococcus, Streptococcus, Corynebacterium, Micrococcus, Enterococcus, Rothia, Bacillus, Neisseria, Haemophilus, Gemella, Globicatella, Granulicatella, Escherichia, Klebsiella, Raoultella, Kluyvera, Enterobacter, Citrobacter, Proteus, Morganella, Pantoea, Pseudomonas, Stenotrophomonas, Candida, Lactobacillus, Bifidobacterium, Bacteroides, Propionibacterium, Veillonella, Clostridium, Ruminococcus, Eggertella, Fusobacterium, Eubacterium, Actinomyces, Collinsella, Prevotella, Campylobacter, Peptoniphilus, Sutterella.

Для уточнения видовой принадлежности 36 изолятов бактерий (SCORE < 2,0) потребовалось секвенирование гена $16 \mathrm{~S}$ PPHK. Для большинства изолятов результаты секвенирования гена $16 \mathrm{~S}$ рPHK совпали с результатами MALDI-TOF масс-спектрометрии. Лишь для 5 изолятов достоверную идентификацию удалось получить только методом секвенирования гена $16 \mathrm{~S}$ PPHK. В ряде случаев точную видовую принадлежность близкородственных микроорганизмов установить не удалось при использовании обоих методов. К таким видам относились: Bifidobacterium kashiwanohense/Bifidobacterium pseudocatenulatum/ Bifidobacterium catenulatum, Lactobacillus casei/Lactobacillus paracasei, Actinomyces naes/undii/Actinomyces viscosus, Actinomyces radingae/Actinomyces ihumii. Расхождение идентификации касалось 11 изолятов: для 7 изолятов методом MALDI-TOF масс-спектрометрии не удалось правильно определить родовую принадлежность микроорганизмов и для 4 изолятов - видовую.

Обобщенные данные по частоте встречаемости и степени микробной обсемененности кишечника новорожденных в зависимости от способа родоразрешения, позволяющие в первом приближении охарактеризовать показатели микрофрлоры здоровых детей, представлены в таблице.

\section{ОБСУЖДЕНИЕ РЕЗУЛЬТАТОВ}

До недавнего времени считалось, что желудочнокишечный тракт новорожденного стерилен в течение
10-20 ч (асептическая фаза) [7], а первичная микробная колонизация при самопроизвольных родах осуществляется за счет микрофлоры влагалища матери, основу которой составляют лактобациллы [8-11]. Между тем появилась и другая точка зрения, основанная на результатах экспериментальных работ [12]. Из недавно опубликованных данных следует, что нормальная микрофлора кишечника у плода закладывается во второй половине беременности от матери при помощи феномена бактериальной транслокации, и утверждение о том, что плод находится в стерильных условиях, оспаривается рядом ученых [13-15]. В нашем исследовании меконий, полученный во время первого акта дефекации в первые часы жизни, был нестерилен у 53 из 66 новорожденных (80\%), что не исключает внутриутробной колонизации.

По данным литературы, в первые часы и сутки жизни происходят активная колонизация и рост кишечной палочки, энтерококков (стадия «нарастающей колонизации»), что не зависит от степени зрелости, перинатальных условий развития плода и вида вскармливания [16-19]. Титр энтеробактерий в этот период достигает $10^{9} \mathrm{KOE} / г$ фекалий [20], тогда как анаэробы - бифидобактерии, лактобациллы, бактероиды обычно отсутствуют [21]. Наши данные свидетельствуют, что в первые часы жизни кишечник колонизировали в основном грамположительные кокки (Staphylococcus spp, Streptococcus spp), причем в большей степени после операции кесарева сечения, чем после родов (частота встречаемости 70 и 60,6\%, титры - до $10^{4}$ и $10^{3} \mathrm{KOE} / г$ соответственно). Энтеробактерии и облигатно-анаэробные микроорганизмы в этот период времени выявляли редко и в низком титре. Вместе с тем, уже в первые часы жизни в составе микробиоты у детей, рожденных естественным путем, чаще, чем при кесаревом сечении, обнаружены бифидобактерии (9 и 3\% соответственно) и лактобациллы (18 и 3\% соответственно). Только у 3\% детей, рожденных самопроизвольно, обнаружены бактероиды. Возможной причиной расхождения наших данных с результатами других авторов является то, что мы старались получить биоматериал непосредственно во время первого акта дефекации новорожденного.

В дальнейшем у здоровых младенцев идет активный рост анаэробной и факультативно-анаэробной составляющей микрофрлоры в количествах $10^{5}-10^{7} \mathrm{KOE} / г$ [15]. K шестым суткам устанавливается равновесие аэробной и анаэробной частей микрофллоры, далее происходит нарастание лакто- и бифидофлоры, и к 2 месяцам жизни она достигает значений $10^{9}-10^{10} \mathrm{KOE} / \Gamma$. По данным других авторов, с 3-5 дня наступает стадия «трансформации микрофлоры», в результате которой происходит вытеснение бифидофлорой других микроорганизмов. В этот период бифидобактерии становятся основной (резидентной) микрофлорой кишечника [22-24]. Доминирующее положение бифидосрлора начинает занимать к 5-20-му дню жизни [25]. Наши данные к 7-м суткам жизни имеют определенные отличия: общее количество микроорганизмов возрастает, достигая 10 10-12 $\mathrm{KOE} /$. Это свидетельствует о том, что равновесие факультативноаэробной и облигатно-анаэробной составляющих микробиоты также наступает к первой неделе, но при более высокой степени микробной колонизации кишечника различными микроорганизмами. Обращает на себя внимание то, что при кесаревом сечении наблюдалось отставание колонизации кишечника 
Таблица. Частота встречаемости, медиана и ИКР степени обсемененности фекалий микроорганизмами

\begin{tabular}{|c|c|c|c|c|c|c|}
\hline \multirow{2}{*}{ Характеристика } & \multicolumn{2}{|c|}{ 1-е сутки жизни $(n=66)$} & \multicolumn{2}{|c|}{ 7-е сутки жизни $(n=52)$} & \multicolumn{2}{|c|}{ 1-й месяц жизни $(n=50)$} \\
\hline & Роды & Кесарево сечение & Роды & Кесарево сечение & Роды & Кесарево сечение \\
\hline \multicolumn{7}{|c|}{ E. coli } \\
\hline Частота встречаемости & $24 \%$ & $9 \%$ & $64 \%$ & $44,40 \%$ & $70,80 \%$ & $61,50 \%$ \\
\hline Медиана (KOE/г) & $10^{2}$ & $10^{2}$ & $10^{8}$ & $10^{9}$ & $10^{9}$ & $10^{9}$ \\
\hline ИКР (KOE/Г) & $10^{2}$ & $10^{2}-10^{3}$ & $10^{8}-10^{9}$ & $10^{8}-10^{10}$ & $10^{8}-10^{10}$ & $10^{8}-10^{10}$ \\
\hline \multicolumn{7}{|c|}{ Другие энтеробактерии } \\
\hline Частота встречаемости & $27 \%$ & $15 \%$ & $68 \%$ & $66,70 \%$ & $66,70 \%$ & $73 \%$ \\
\hline Медиана (KOE/г) & $10^{3}$ & $10^{3}$ & $10^{9}$ & $10^{9}$ & $10^{9}$ & $10^{9}$ \\
\hline ИКР (KOE/Г) & $10^{2}-10^{4}$ & $10^{2}-10^{3}$ & $10^{8}-10^{10}$ & $10^{9}-10^{10}$ & $10^{8}-10^{10}$ & $10^{9}-10^{10}$ \\
\hline \multicolumn{7}{|c|}{ Грамположительные факультативно-анаэробные и аэробные бактерии } \\
\hline Частота встречаемости & $60,60 \%$ & $70 \%$ & $100 \%$ & $100 \%$ & $100 \%$ & $100 \%$ \\
\hline Медиана (KOE/г) & $10^{2}$ & $10^{2}$ & $10^{8}$ & $10^{9}$ & $10^{8}$ & $10^{9}$ \\
\hline ИКР (KOE/Г) & $10^{2}$ & $10^{2}-10^{3}$ & $10^{8}-10^{10}$ & $10^{8}-10^{10}$ & $10^{7}-10^{9}$ & $10^{7}-10^{9}$ \\
\hline \multicolumn{7}{|c|}{ Бифидобактерии } \\
\hline Частота встречаемости & $9 \%$ & $3 \%$ & $84 \%$ & $33 \%$ & $83,30 \%$ & $53,80 \%$ \\
\hline Медиана (KOE/г) & $10^{2}$ & $10^{2}$ & $10^{11}$ & $10^{10}$ & $10^{11}$ & $10^{10}$ \\
\hline ИКР (KOE/Г) & $10^{2}-10^{3}$ & $10^{2}$ & $10^{9}-10^{11}$ & $10^{6}-10^{11}$ & $10^{10}-10^{12}$ & $10^{10}-10^{11}$ \\
\hline \multicolumn{7}{|c|}{ Лактобациллы } \\
\hline Частота встречаемости & $18 \%$ & $3 \%$ & $28 \%$ & $37 \%$ & $58,30 \%$ & $69 \%$ \\
\hline Медиана (KOE/г) & $10^{2}$ & $10^{2}$ & $10^{8}$ & $10^{8}$ & $10^{8}$ & $10^{8}$ \\
\hline ИКР (KOE/Г) & $10^{2}$ & $10^{2}$ & $10^{6}-10^{10}$ & $10^{6}-10^{10}$ & $10^{5}-10^{10}$ & $10^{7}-10^{10}$ \\
\hline \multicolumn{7}{|c|}{ Бактероиды } \\
\hline Частота встречаемости & $3 \%$ & 0 & $32 \%$ & 0 & $25 \%$ & $3,80 \%$ \\
\hline Медиана (KOE/г) & $10^{2}$ & 0 & $10^{9}$ & 0 & $10^{10}$ & $10^{9}$ \\
\hline ИКР (KOE/Г) & $10^{2}$ & 0 & $10^{9}-10^{11}$ & 0 & $10^{10}$ & $10^{9}$ \\
\hline \multicolumn{7}{|c|}{ Клостридии } \\
\hline Частота встречаемости & 0 & 0 & $32 \%$ & $40,70 \%$ & $33,30 \%$ & $65,40 \%$ \\
\hline Медиана (KOE/г) & 0 & 0 & $10^{7}$ & $10^{9}$ & $10^{10,5}$ & $10^{9,5}$ \\
\hline ИКР (KOE/Г) & 0 & 0 & $10^{6}-10^{9}$ & $10^{6}-10^{10}$ & $10^{6}-10^{11}$ & $10^{8}-10^{10}$ \\
\hline
\end{tabular}

бисидобактериями и преобладание прочих строгих анаэробов (в основном вейлонелл, клостридий).

$\mathrm{K}$ концу первого месяца жизни анаэробная часть микробиоты заняла лидирующее положение с доминированием бифидофлоры в обеих группах. Тем не менее после кесарева сечения бифидослора была выявлена лишь у половины детей, тогда как после самопроизвольных родов этот показатель достиг 83\%.

Характерные для детей первого года жизни B. longum subsp. infantis, B. animalis subsp. lactis, B. breve, B. bifidum обладают противовоспалительным действием и способствуют формированию Тh1-иммунного ответа. Преобладающие штаммы бифидобактерий у взрослых - B. longum subsp. longum, B. adolescentis, B. pseudocatenulatum - способствуют Тh2-иммунному ответу и превалируют в микробиоте кишечника при ожирении [24]. Кроме того, В. longum subsp. infantis отличается наличием в геноме кластера, кодирующего синтез ферментов (сиалидазы, фукозидазы, N-ацетил$\beta$-гексозаминидазы и $\beta$-галактозидазы), расщепляющих олигосахариды до моносахаридов [25]. Бифидофлора кишечника в течение всей жизни остается превалирующей и является апатогенной, в то время как иные представители облигатной микрофрлоры при определенных условиях могут стать причиной заболевания [13]. Полученные нами результаты показали, что после операции кесарева сечения у новорожденных доминируют не самые полезные виды бифидобактерий, в частности, не способные расщеплять лактозу (B. animalis, $B$. dentium, B. ruminantium).

\section{ВЫВОДЫ}

Полученные нами результаты подтверждают, что оперативное родоразрешение в определенной степени сдерживает процесс нормального становления микробиоты кишечника. В дальнейшем мы планируем продолжить накапливать информацию о состоянии микробиоты у данной категории детей и расширить исследование, включив в него недоношенных детей, с целью определения критериев нормы кишечной микробиоты здоровых доношенных новорожденных. Проведенное исследование позволило создать, а в перспективе пополнять коллекцию лактобацилл и бифидобактерий, выделенных у здоровых доношенных новорожденных для 
выявления бактерий - претендентов в пробиотические штаммы. Своевременная адекватная оценка состава микробиоты новорожденных по показателям ключевых биомаркеров позволит проводить направленную профилактику ближайших и отдаленных последствий перинатальной патологии у доношенных и недоношенных новорожденных путем ее коррекции с использованием адекватной композиции пробиотиков.

\section{Литература}

1. ОСТ 91500.11.0004-2003. Протокол ведения больных. Дисбактериоз кишечника. Утв. Приказом МЗ РФ № 231 от 09.06.2003. Москва, 2003; 173 с.

2. Методические рекомендации «Бактериологическая диагностика дисбактериоза кишечника». Минздрав РСФСР. 1977.

3. Методические рекомендации «Микробиологическая диагностика дисбактериоза кишечника». Москва, 2007.

4. Gronlund MM. Arvilommi H, Kero P, Lehtonen OP, Isolauri E. Importance of intestinal colonization in the maturation of humoral immunity in early infancy: a prospective follow up study of healthy infants aged 0-6 months. Arch Dis Child Fetal Neonatal. 2000; 83 (3): 186-92.

5. Леванова Л.А. Микроэкология кишечника жителей Западной Сибири, коррекция дисбиотических состояний [диссертация]. М., 2003.

6. Щербаков П. Л., Нижевич А. А., Логиновская В. В., Щербакова М. Ю., Кудрявцева Л. В., Митрохин С. Д. и др. Микроэкология кишечника у детей и ее нарушения. Фарматека. 2007; (14): 28-34.

7. Акоев Ю. С. Функциональные особенности недоношенных детей в раннем онтогенезе [диссертация]. М., 1999.

8. Копанев Ю. А., Соколов А. Л. Дисбактериоз кишечника: микробиологические, иммунологические и клинические аспекты микроэкологических нарушений у детей. М., 2002.

9. Степурина О. В. Первичное инфицирование ребенка. Инфекционные заболевания детей и экология человека. Ставрополь, 1999; 92-7.

10. Фролова Н. А. Особенности формирования микробиоценоза у детей раннего возраста в зависимости от микробного пейзажа кишечника матери [диссертация]. Смоленск, 2001.

11. Никитенко В. И., Ткаченко Е. И., Стадников А. А. Транслокация бактерий из желудочно-кишечного тракта - естественный защитный механизм. Эксперимент. и клин. гастроэнтерол. 2004; (1): 48

12. Funkhouser LJ, Bordenstein SR. Mom knows best: the universality of maternal microbial transmission. PLoS Biol. 2013; (11): e1001631.

\section{References}

1. OST 91500.11.0004-2003. Protokol vedeniya bol'nykh. Disbakterioz kishechnika. Utv. Prikazom MZ RF № 231 от 09.06.2003. Moscow, 2003, 173 p.

2. Metodicheskiye rekomendatsii "Bakteriologicheskaya diagnostika disbakterioza kishechnika" Minzdrav RSFSR. 1977.

3. Metodicheskiye rekomendatsii "Mikrobiologicheskaya diagnostika disbakterioza kishechnika". Moskva, 2007.

4. Gronlund MM. Arvilommi H, Kero P, Lehtonen OP, Isolauri E. Importance of intestinal colonization in the maturation of humoral immunity in early infancy: a prospective follow up study of healthy infants aged 0-6 months. Arch Dis Child Fetal Neonatal. 2000; 83 (3): 186-92.

5. Levanova LA. Mikroekologiya kishechnika zhitelej Zapadnoj Sibiri, korrekciya disbioticheskih sostoyanij [dissertation]. M., 2003.

6. Shcherbakov PL, Nizhevich AA, Loginovskaya W, Shcherbakova MYu, Kudriavtseva LV, Mitrokhin SD, et al. Mikroekologiya kishechnika u detey i yeye narusheniya. Farmateka. 2007; (14): 28-34.

7. Akoyev YuS. Funktsional'nyye osobennosti nedonoshennykh detey v rannem ontogeneze [dissertation]. M., 1999.

8. Kopanev YuA, Sokolov AL. Disbakterioz kishechnika: microbiologicheskiye, immunologicheskiye i klinicheskiye aspekty
13. Muglia LJ, Katz M. The enigma of spontaneous preterm birth. $\mathrm{N}$ Engl J Med. 2010; 362: 529-35.

14. Onderdonk AB, Hecht JL, McElrath TF, Delaney ML, Allred EN, Leviton A. Colonization of second-trimester placenta parenchyma. Am J Obstet Gynecol. 2008; 199: 51-2.

15. Соловьева И. В., Белова И. В., Точилина А. Г., Ефимов Е. И., Пожидаева А.С. Формирование микрофлоры толстой кишки у детей. Микробиологический и эпидемиологический вестник Нижегородского университета им. Н. И. Лобачевского. 2012; (2-3): 93-9.

16. Fanaro S, Chierici R, Guerrini P, Vigi V. Intestinal microflora in early infancy: composition and development. Acta pediat. 2003; 91 (441): 48-55.

17. Orrhagt $\mathrm{K}$, Nord $\mathrm{CE}$. Factors controlling the bacterial colonization of the intestine in breastfed infants. Acta Pediatr. 1999; 88 (430): 47-57.

18. Edwards CA, Parret AM. Intestinal flora during the first months of life: new perspectives. Br J Nutr. 2002; 88 (11): 11-8.

19. Goldman AS. Modulation of the gastrointestinal tract of infants by human milk. Interfaces and interactions. An evolutionary perspective. J Nutr. 2000; 130 (2): 426-31.

20. Нетребенко О. К. Питание грудного ребенка и кишечная микрофрлора. Педиатрия. 2005; (3): 53-7.

21. Ткаченко Е. И., Суворова А. Н., редакторы. Дисбиоз кишечника. Руководство по диагностике и лечению. СПб. ИнформМед, 2009; 276 c.

22. Шабалов Н. П. Неонатология. М.: Медпресс-инсрорм, 2004; c.128-29.

23. Нетребенко О. К. Питание и развитие иммунитета у детей на разных видах вскармливания. Педиатрия. Журнал им. Г. Н. Сперанского. 2005; (6): 50-6.

24. Печкуров Д. В., Турти Т. В., Беляева И. А., Тяжева А. А. Микробиота кишечника у детей: от профилактики нарушений становления к предупреждению неинфекционных заболеваний. Педиатрическая фармакология. 2016; 13 (4): 377-83.

25. Суворов А. Н. Микробиота детей. Природа. 2011; (8): 14-21. mikroekologicheskikh narusheniy u detey. M., 2002.

9. Stepurina OV. Pervichnoye infitsirovaniye rebenka. Infektsionnyye zabolevaniya detey i ekologiya cheloveka. Stavropol', 1999; 92-7.

10. Frolova NA. Osobennosti formirovaniya mikrobiotsenoza u detey rannego vozrasta $\vee$ zavisimosti ot mikrobnogo peyzazha kishechnika materi [dissertation]. Smolensk, 2001.

11. Nikitenko VI, Tkachenko El, Stadnikov AA. Translokatsiya bakteriy iz zheludochno-kishechnogo trakta - yestestvennyy zashchitnyy mekhanizm. Eksper i kiln gastroentorolog. 2004; (1): 48.

12. Funkhouser $L J$, Bordenstein SR. Mom knows best: the universality of maternal microbial transmission. PLoS Biol. 2013; (11): e1001631.

13. Muglia LJ, Katz $\mathrm{M}$. The enigma of spontaneous preterm birth. $\mathrm{N}$ Engl J Med. 2010; 362: 529-35.

14. Onderdonk AB, Hecht JL, McElrath TF, Delaney ML, Allred EN, Leviton A. Colonization of second-trimester placenta parenchyma. Am J Obstet Gynecol. 2008; 199: 51-2.

15. Solov'yeva IV, Belova IV, Tochilina AG, Efimov El, Pozhidaeva AS. Formirovaniye mikroflory tolstoy kishki u detey. Mikrobiologicheskiy i epidemiologicheskiy vestnik Nizhegorodskogo universiteta imeni N. I. Lobachevskogo. 2012; (2-3): 93-9. 
16. Fanaro S, Chierici R, Guerrini P, Vigi V. Intestinal microflora in early infancy: composition and development. Acta pediat. 2003; 91 (441): 48-55.

17. Orrhagt $\mathrm{K}$, Nord CE. Factors controlling the bacterial colonization of the intestine in breastfed infants. Acta Pediatr. 1999; 88 (430): 47-57.

18. Edwards CA, Parret AM. Intestinal flora during the first months of life: new perspectives. Br J Nutr. 2002; 88 (11): 11-8.

19. Goldman AS. Modulation of the gastrointestinal tract of infants by human milk. Interfaces and interactions. An evolutionary perspective. J Nutr. 2000; 130 (2): 426-31.

20. Netrebenko OK. Pitaniye grudnogo rebenka i kishechnaya mikroflora. Pediatriya. 2005; (3): 53-57.
21. Tkachenko El, Suvorova AN, editors. Disbioz kishechnika. Rukovodstvo po diagnostike i lecheniyu. SPb. InformMed, 2009; $276 \mathrm{p}$.

22. Shabalov NP. Neonatologiya. Moscow: Medpress-inform, 2004; p. 128-9.

23. Netrebenko OK. Pitaniye i razvitiye immuniteta $u$ detey na raznykh vidakh vskarmlivaniya. Pediatriya. Zhurnal imeni G. N. Speranskogo. 2005; (6): 50-6.

24. Pechkurov DV, Turti TV, Belyaeva IA, Tjazheva AA. Intestinal microflora in children: from formation disturbances prophylaxis to preventing non-infectious diseases. Pediatric pharmacology. 2016; 13 (4): 377-83.

25. Suvorov AN. Mikrobiota detey. Priroda. 2011; (8): 14-21. 